\title{
Results of educational, experimental, research design of modern entertainment objects in Kielce by students of Lviv Polytechnic University and Politechnika Swietokrzyska Kielce University of Technology
}

Abstract

The article highights the results of modern entainment buildings design in Kielce performed by Ukrainian and Polish students. Duing the workshop students focused on designing moden peftormance architecture, in a sense of architecture-formal solutions, concept of forming the creative environment according to the demands of Polish and the world nowadays. All projects of Polish and Ukrainian students, mentioned in the article, are prepared under the guidance of Professor V. Pro-

Keywords: theatrical and show, cultural-educational, recreation and entertainment objects.

1. Introduction

Kielce is known in Poland not only as a highly ecological city, possessing extremely qualitative drinking water, having within its building area water basins, rivers, springs enriched with clean winds and the sun, it is practically located in Swietokrzyskie Mountains. The city is conveniently conand the capital city Warsaw via railways and roads. It has unique historical architecture monuments, buildings and constructions of cultural-entertaining activity, famous and cationat institions and spot centers. As to the objects of the culturatering the culural-erions and sport ceer Winnizk and Moniche Winizka and Mrits and activity concepts which correspond to the ideas of the $X X$ century. Though, the certain aspects of the entertaining activity oriented on the demands of the XXI century are realized in Kielce by H.Sinkevycha street, Rynok sqaure, park of Staszica, gallories 'Echo' and 'Crown' - some problems still remain. That is why the projects of the students from Lviv Polytechnic University and Pollechnika Swietokrzyska Kielce University of Technology directed onto modern entertainment objects in Kielce are vital. Modern in sense of architecture-formal solutions, concept of forming the creative environment according to the demands of Poland and the world nowadays.
2. The main part

Among the best projects of the Polish students one can find "Centrum Wystawiennicze przedstawien teatralnyh I performansow $\mathrm{w} \mathrm{m}$. Kielcen, author - the student D.Kicior. Project of the theatre for the rock performances and concerts in Kielce "A. Wojcieszak "Project interaktywne centrym sztuki na ulicy Lesnej w Kielcach" - author Iwona Preiss "Palac Kul" au" performed by Skrobasz Do

Project of the library quarter in Kielce (ill. 2) author - student Monika Zmarzly and other works.

Among the projects of the Ukrainian students the following works deserve to be acknowledged "Shopping and leisure centre" in Kielce by the student N.Mashkevych (ill. 3), International student cultural center by the student $\mathrm{O}$. Dmytrash, «Project of the entertaining center in Kielce within the streets Krakivska Ogrodova

The project "Centrum Wistawiennicze przedstawien teatralnych i performansow $\mathrm{w}$ m. Kielce" D. Kicior designed on the Wolnosci square, which main axis is parallel to
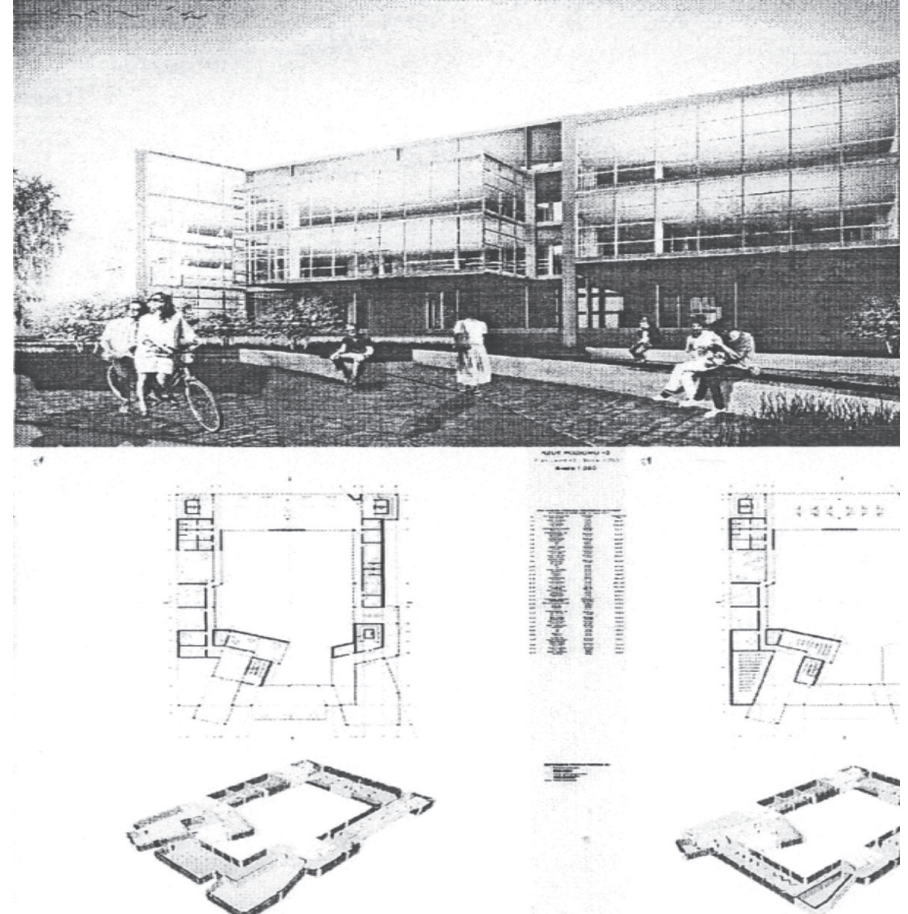

$\equiv$

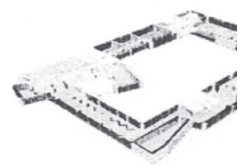

III. 1 "Palac Kultury Studentow" performed
II. 2 Project of the library quarter in Kielce

III. 3 «Shopping and leisure centre» in Kielce by the student N.Mashkevych
III. 4 "Centrum Wistawiennicze przedstawien teatralnych i performansow

III. 4 "Centrum Wist Kielce" D. Kicio

Дизайн торгово-розважального центру в місті Кельце
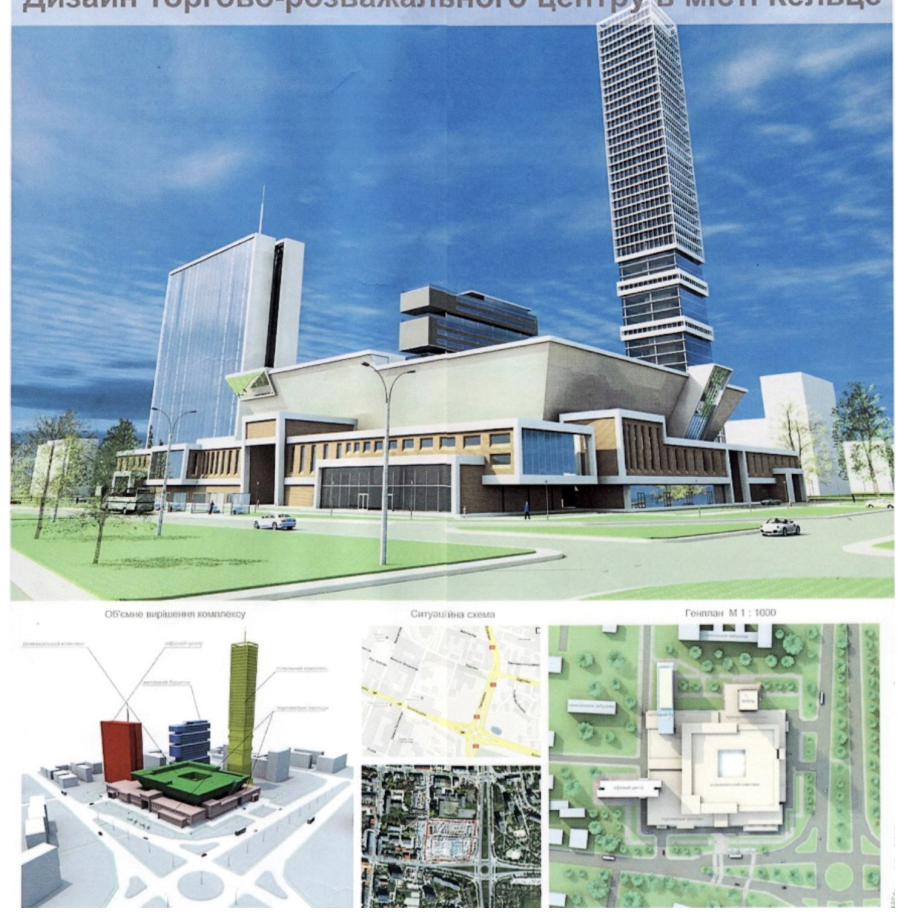

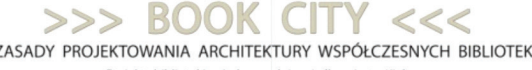

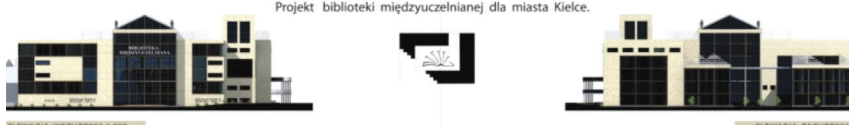

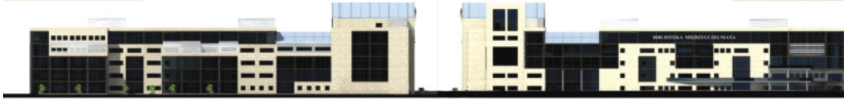

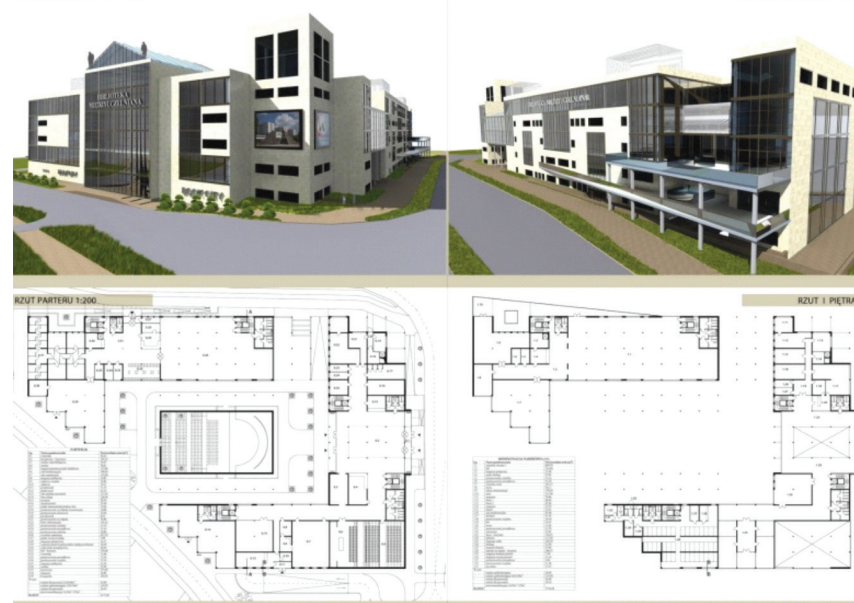


H.Sinkevycha Street and directed onto the main cathedrals of the town. Idea for creation of the current object was provoked by the desire of the author to find such a building, where simultaneously all possible theater and show performances, concerts, installations of both classical- 'live' - and modern character - electronic - can coexist. Which environment includes not only interiors of the complex building, but also facade exteriors along its contour and even the environment of the square itself, the streets located nearby and the city of the square the form of the supremtic cubes, which seem to be hanging or grown from the min volume of the bulding, where the big biggest theater halls win volume of th

Objects located around the perimeter can host experimental 'live' performances, and their facades will serve as the screens projecting the actions inside each of them, as well as shows and installations taking place simultaneously in all the areas. Thus, the facades-screens will turn the environment of the Woinosci square into the great auditory hall under the sky and these facades-screens will be able to broadcast the performance or the other event available for electronic transfer while it is actually taking place outside of the city. Available for the spectators both in any part of the world and in Kielce (ill. 4).

Project by Marta Mykyta from Lviv «Project of the entertaining center in Kielce within the streets Krakivska - Ogrodovan is a bit more modest but not less simple. This object is located on the territory of the degraded gar den square in front of Marzalka Pilsudskiego square The author designed the center in such a way that all of its facades perform the much function, depending on the stret the visitors come from. Moreover, the author designed the center in such a way, that all funcigned spaciat components of the object mayberead from outside - the com object may be read from being on the street, defines on what floor and being on the street, defines on what floor and in what part or the building the space-premise is located and how to get there. Whether it is the ground floor with a parking lot, bowling shopping space, cafes, restaurants, gyms, ex-

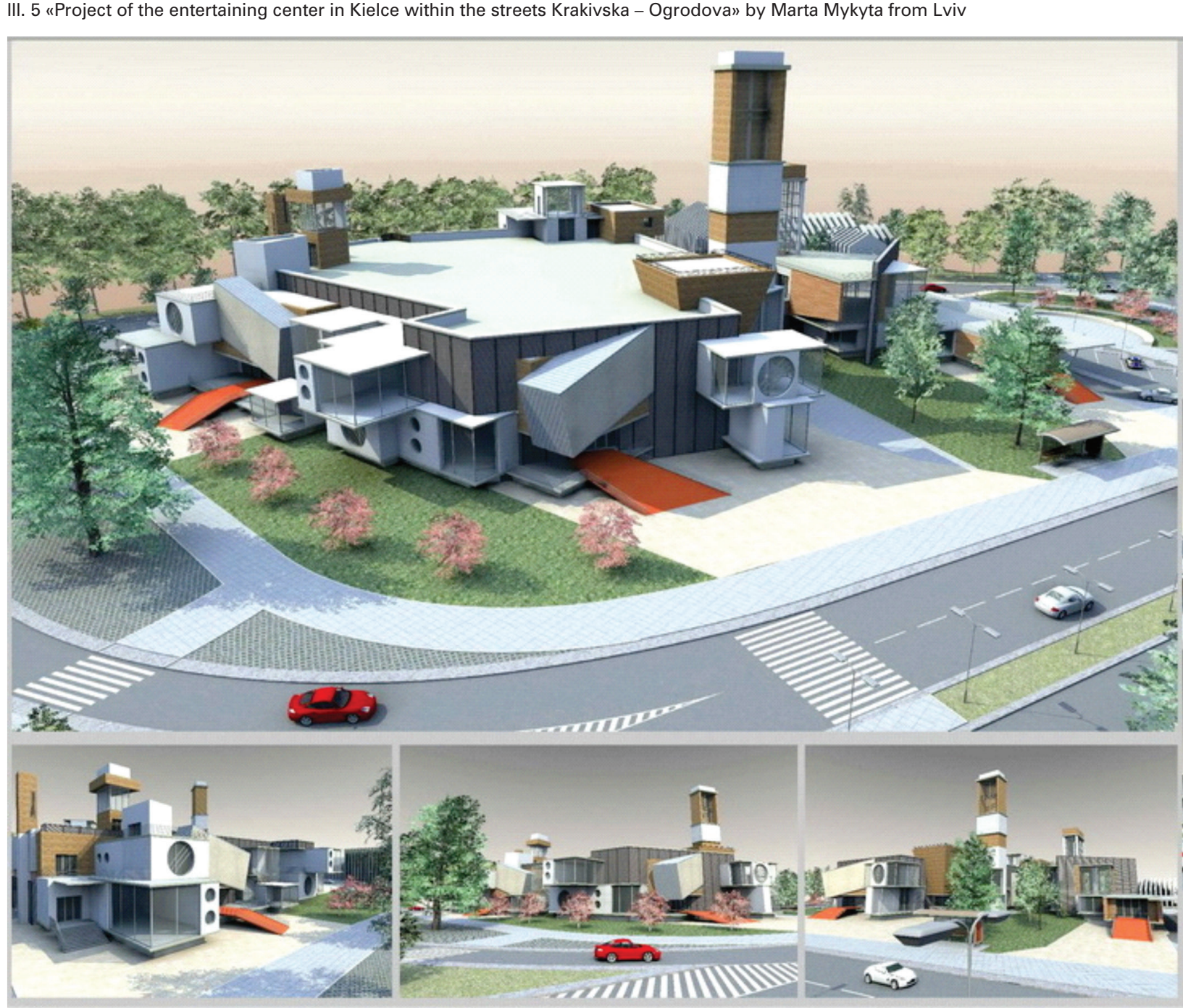

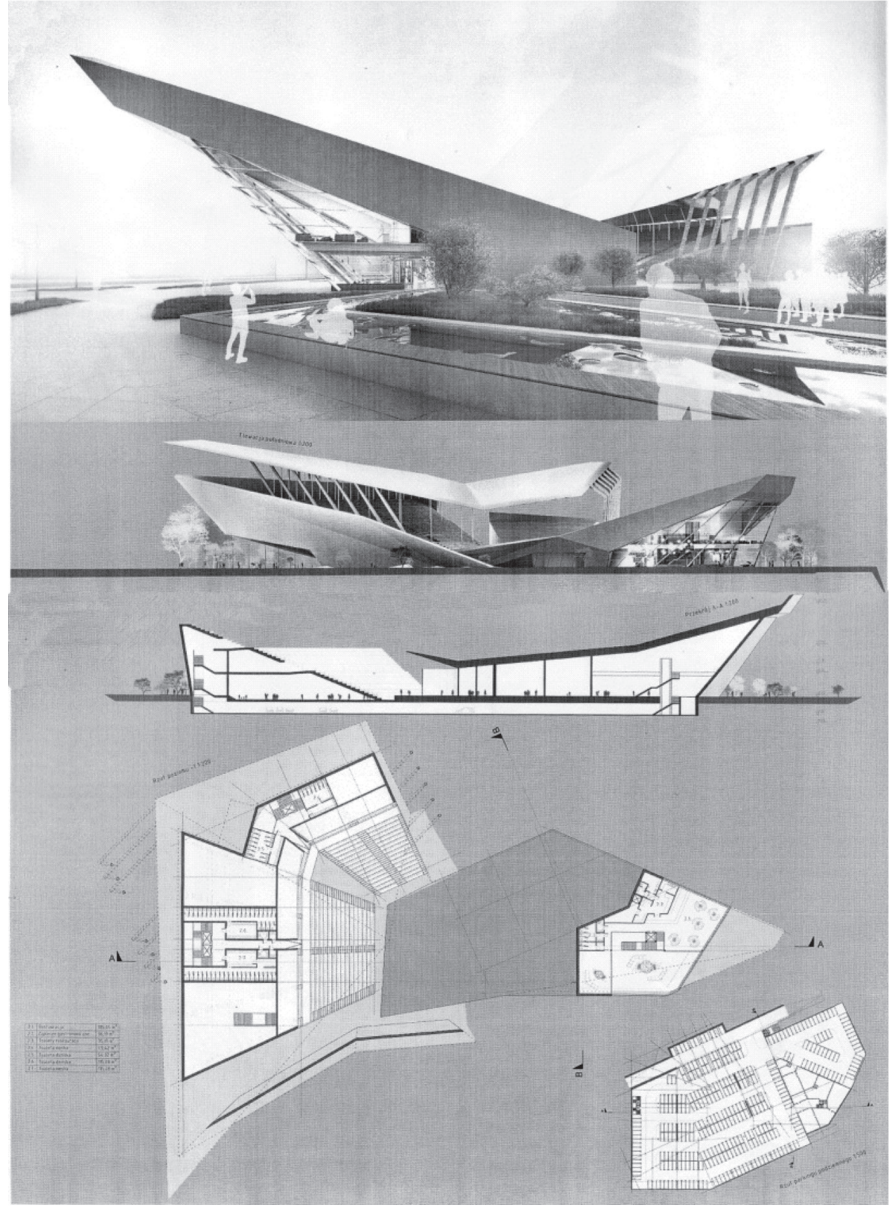

III. 6. 'Theater for performances and concerts in Kielce' by A. Wojcieszak

hibition and club premises. Or cinema halls, multimedia, club, exhibition, universal premises and spaces on the first floor The author selected coloristics as a mean of integration of the new-built into the exiting environment, making the complex in whole similar in colouring to the historical buildings of the city surrounding the 'center'. Following the idea of the author, the ruins preserved on Ogrodowa Street should be restored and the function they fulfilled in the historical times - renewed (ill. 5).

A. Wojcieszak selected the land plot on the place of the existing city market, located at the corner of Seminaryiska I Tarnowska streets, for the project Theater for performances and concerts in Kielce. The building was designed with its main axis coinciding with the diagonal of the land plot, looking like a majestic bird from concrete, glass and metal, which seem to sit down for a minute in Kielce ready to fly further demonstrating the character of the shows the building is designed for with dynamics, tectonics and rhythm of architecture.

One more proof which encouraged the author to design the object on that very place a building for several thousand places on the verge of the historical city center - the place for entertainment of youth should be inside of the city, and not outside of it or in the reservarion ares. Thus it possible to grow the young people ther socia groups and always resionte to ony tify themselves with the hi environment of the city.

Vurrent 'center' is formed with the three main components, three-level tiered stalls with vertical communications, which sectors are connected through galleries with sanitary-technical and all-purpose premises underneath them. All of this in the bigger 'wing'.

The smaller 'wing' has chamber concert halls, spaces for casting, offices, mini-bar, lobby, and there is a space of the scene, which is provided for the spacial, functional and technological transformations. The author designed a parking lot for 300 vehicles (ill. 6). in the contours of the building on the minus markers. All projects of Polish and Ukrainian students, mentioned in the article, are prepared under the guidance of professor V.Proskuriakov, projects of the Ukrainian students also involved the master T.Harashchak.

BIBLIOGRAPHY

[1] Viktor Proskuryakov. The development of progressive
typological ideas by architectural schools from Lviv and

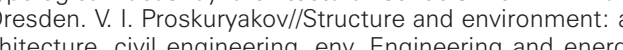
- No 2/2011, vol. 3. - PL ISSN 2081-1500 [2] Proskuryakov. chitectural schools of Lviv and Kielce polytechnics /V. I. Proskuryakovv, I. S. Voronkova al/siructure and environment: ar-

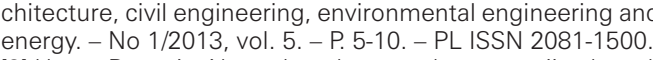
[3] Haupt Patrycja, Naturaline elementy kompozycji w ksztalku z otoczeniem. Monografia 514 seria Architektura Poltechnika Krakowska, Krakow 2015 